\title{
Life Below Water: Role of Traditional Artisanal Fisheries to Ensure Sustainable Tourism in Karimunjawa Island
}

\author{
Alifia Afflatus Zahra ${ }^{11}$, Noor, Naelil Masruroh ${ }^{2}$ \\ ${ }^{1}$ Bachelor Program of History, Faculty of Humanities, Universitas Diponegoro \\ ${ }^{2}$ Bachelor Program of History, Faculty of Humanities, Universitas Diponegoro
}

\begin{abstract}
The society of Karimunjawa Island is one of a highly enticing tourism destination that maintains the rich practice of artisanal fisheries based on traditional culture and people consensus. This study focuses on artisanal fisheries conducted by Bugis and Bajau nomad descent. Thus, it examines the pattern and dynamics of Bugis and Bajau artisanal fisheries culture in Karimunjawa. They perform alternate short range and nomadic fishing, as well as fishing for market supplies nor solely domestic supplies in which consider ecological conservation and sustain tourism. By means of qualitative method through literature studies and interviews, this research offers case study-based solution to support Sustainable Development Goals number 14, Life Below Water, in which unfolds the method of the Karimunjawa Bugis and Bajau style of artisanal or small scale fisheries through selective fishing gears for subsistent purpose. This research concludes that Bugis and Bajau artisanal fisheries result to minimized exploitation as well as mindful fisheries that preserves underwater biodiversity and supports Life Below Water, which eventually engenderrs cultural-based sustainable tourism in Karimunjawa Island, Jepara regency, Central Java, Indonesia.
\end{abstract}

\section{Introduction}

To support oneself within the modern society, each country worldwide has its particular way to increase wealth from the tourism sector. It comprises to develop not only land but also maritime tourism. Maritime tourism emphasises utilising marine resources accountable for growth, including marine biodiversity, coastal areas, and maritime society. As an integrated tourism-dependent on natural maritime attraction, it shows significance in advancing the local economy, marked by the development and standards raised of the coastal cities. However, due to the unpredictability of nature, its sustainability demands more attention. In many cases, there is no strategise enough plan for develop maritime tourism while also managing the ecosystem sustainability $[1,2,3,4]$.

Indonesia - as well as the other Asia Pacific countries whose tourism sector relies on the coastal area - consists of thousands of small islands. Indonesia maintains an image of the archipelagic country, with a rich indigenous culture that differs from the dominating western

* Corresponding author : alifia.afflatus@email.com 
culture as the typical concept of modern global civilisation. As tourism grows by sacrificing its pristine coasts and marine, it needs more than planning an economic-oriented tourist attraction. Question of how to retain its environmental components-besides its cultural values-in a good state becomes essential, for instance, its natural biodiversity and ecosystem balance. Reaching the era of Anthropocene, it is everyday awareness that tourism and human progress (technology, innovation) and activities generally risks the environment through pollution, waste, and severe threats towards resources, as society and nature is impossible to disentangle $[1,5]$.

The United Nations popular global agenda adopted by 193 member states in September 2015, Sustainable Development Goals (SDG's) 2030, has already included the maritime environment as one of seventeen goals to achieve. Sustainability, in general, is indicated by three significant aspects, namely environment, social, and economic situation [6]. It is goal number 14, titled "Life Below Water", containing several sub-targets that range on many aspects of the maritime environment. On its official website, it is mentioned that several indicators could mark its achievements. The actions to support marine sustainability could be establishing a particular Marine Protected Area (MPA) line, which manages biological and physical factors and involves social (human) variables. It is concluded that humans become the MPA's stakeholders as a tool or strategy to maintain the ecosystem [7].

Karimunjawa Islands is one of the marine tourism destinations in Central Java which has become a conservation area under the Karimunjawa National Park. The development history of the Karimunjawa areas cannot be separated from when the Dutch colonial managed the island. Karimunjawa was designed as a defence area to control pirates around the Java Sea [8]. Multiculturalism has become a characteristic of Karimunjawa's society, consisting of various maritime ethnicities, including Bajau and Bugis. They have local knowledge in sustainable marine environmental management. It is performed due to the awareness that the sea is an inseparable part of their lives and future generations, so they need to take responsibility to ensure that marine resources continue to guarantee their current and future needs. Their ability to manage fishery resources can be considered part of the artisanal fisheries practices, which depend on the interaction between humans and the marine ecosystem. In addition, their knowledge about fisheries and other resources, collective local institutional arrangements, market interactions, and decision-making processes in fishing activities are considered the artisanal fisheries components [9]. Therefore, local practices carried out by the Bajau and Bugis are relevant to achieving SDG goal number 14.

At least, there are several studies regarding the socio-cultural conditions of the Karimunjawa society and their local knowledge to manage marine areas sustainably. The study conducted by Rochwulaningsih et al. [8] can identify inter-ethnic relationships in Karimunjawa, who lived in the area for decades. The study informed that the Bugis descent is always considered to be Kemojan people because most of them lived in Kemojan Village, $30 \%$ of them lived in the village. However, generally, the Bugis descent in Karimunjawa are also scattered in several villages apart from Kemojan. As many as $11 \%$ of the Bugis are in Karimunjawa, 3\% in Parang, and 2\% in Nyamuk. In her study, what has been achieved by Rochwulaningsih, also confirmed by Suliyati [10], who argues that the presence of the Bugis and Bajau descents in Karimunjawa is considered to have a harmony in preserving culture and traditions related to local knowledge on marine navigation routes.

Highlighting the potential of artisanal fisheries culture that is claimed to be more environment- friendly, this paper studies and prove the claim, as well as proposing a strategy of using artisanal fisheries to be capable of supporting the maritime sustainability-related goals based on a case study in Karimunjawa Island, Jepara Regency, Central Java, Indonesia. Artisanal fisheries performed by Bugis and Bajau descents with their traditional fishing and shipping activities can be a method to reach the goals of Life Below Water. This study also 
examines that underwater biodiversity may boost local economics through marine ecotourism, which also address an issue related to sustainable tourism.

\section{Method}

This research employs a qualitative method in which literature studies and an interview are conducted within information gathering. To ensure the novelty and relevance of today's phenomenon, this paper cites international primarily and national scientific publications spanning from 2016 up to 2021. However, publications beyond that restricted range are somehow cited only if the substance discusses topics that require authenticity and does not enforce novelty and innovation, such as progress, traditional culture, and history of Bajau and Bugis communities. To answer and examine the problems, this study uses an ecosystem approach to emphasize the integrated management of water and living resources in conserving and sustaining the ecosystem. The ecosystem approach recognizes community with their knowledge and wisdom to treat nature equitably [11].

\section{Results and discussion}

\subsection{Geographical Background}

Karimunjawa is located $120 \mathrm{~km}$ north of the capital of Central Java, with rich mangrove forest, $132 \mathrm{~km} 2$ of coral reefs that are developed on sand-topped banks that, for instance, are present in its small islands Menjangan Kecil, Menjangan Besar, Kemujan, and Karimunjawa [12]. Karimunjawa Island comes as an option due to its rich artisanal fisheries culture and intense international maritime tourism. In this case, several social variables are observed. The stakeholders incorporate the artisanal fishing communities in Karimunjawa, law enforcement authorities, and tourists. It is not limited to finding its applicability in Indonesian maritime tourism, yet this strategy is also expected to demonstrate in the other archipelagic countries that depend on maritime tourism.

\subsection{The Local Wisdom of Karimunjawa Fisheries by the Bajau and Bugis Descent}

Notwithstanding the multi-ethnicity of maritime society in Karimunjawa Island, Bajau and Bugis descendants are highlighted in this paper due to their richness of maritime culture, including their fishing technology. Unlike the Javanese and Madura people, Bajau and Bugis people are popularly known to migrate from the other part of Southeast Asia as sea nomads. Their spread as a maritime ethnic could be tracked since the 16th century. The encounter with European traders and colonizers became one of the factors that support diaspora groups. The destructive conflict with the VOC during 1670 in Tosora, the capital of Bugis kingdom, created an intense flow of Bugis refugees and their Makassar counterparts to other parts of Nusantara, namely Malay, Sumatera, and Java. Despite migrating to Java, the Bugis people - who were successfully surviving their civilization - opted a clever strategy by seeking refuge in the strong kingdoms in Mataram, Madura, Palembang, and Jambi, as these host kingdoms became a solid basis for guarding their nomadic maritime culture. Being exposed to Islamism, Bugis people were divided into orthodox and syncretic communities, where the syncretic or traditional Bugis communities brought traditional unorthodox characters such as Sawarigading as a local figure of Prophet Muhammed, positioning to-alusu (spiritual entities) and (to-tenrita) as the intermediaries of Allah, and practicing rituals in which portrayals are 
symbolized in their crops, settlements, fishing, and boats, which often took place in the seashore or river banks[13, 14].

Meanwhile, Bugis people have also settled in the land area; the maritime people of Bugis descents consume fish, often preserved by salting, smoking, or sun-drying them as a daily meal. They also normally purvey raw foods such as shrimps, cuttlefish, squids until seaweeds. Traditional Bugis practices fishing and fish farming as subsistence activities other than agriculture, ranging from coastal and deep fishing, fish farming up to freshwater as the ground. Flying fish hunting in the deep sea becomes popular in Bugis mythology, which occurs during the East Monsoon. This practice proceeds using small-scale bamboo lath basket traps with $75 \mathrm{~cm}$ length and $25 \mathrm{~cm}$ diameter that prevent the fish from releasing mostly ten baskets per boat. Completed with floats, the basket trap is hung for three to four hours with the goose - a type of seaweed, on the vessel. They also use romping or a bamboo raft to catch scads and batfish that trap the fishes by the gills. Puka' or rectangular drift nets are utilized to catch tuna fish and scads. Other subsistent gears they use include hand lines with sinkers, with either hooks or slipknots to catch deep fishes, bagang - a floating or planted platform that attracts pony fish, anchovy, scad, sardines, and cuttlefish that only catches when it is not a full moon, banrong or the horizontal dip-net until shore seines (sesse) that takes a boat and around twelve men to pull towards the shore. The Bugis people also popularly use belle that catches demersal fish by bamboo or wooden fences as the trap, usually attracting mullets, ladyfish, grunter, sea perch, pig-face bream, parrotfish, until garfish. Salekko - in the end - is a cone basket trap that carries shallow water fish and crustaceans by hand [14]. The rich variations of fishing gears emerged due to their subsistent need to survive their wellbeing in different natural conditions. Each gear demonstrates different functions to catch particular fish and fishing grounds, which shift during particular weather, breeding season, and other natural factors. This allows time and space for particular species to reproduce and grow. At the same time, the Bugis seamen hunt for the other groups of species, which artlessly embodies the ecosystem biodiversity equilibration.

The preservation of their complex fishing culture was induced by their tendency to penetrate and dominate the existing communities, rather than assimilating or isolating themselves in the host areas. They were meticulous in developing fisheries, besides maritime trading links. Little did people notice that these traditional seafarers have sophisticated ecological awareness that still resonates with their ethnographic character. Whether mystic rituals of orthodox Islamic practices are applied before their voyages, which in their belief is to ensure safety and speed, they also pay attention to the monsoon winds, altitude, phase, tides, and natural factors their canoe-fare depends on $[15,16]$.

Besides Bugis, the Bajau people (alternatively written as Bajo or Bajao) are another existing migrant community in Karimunjawa Island that provides ideal subsistent fisheries. Virtually, they predominantly amass around Sulu in the Philippines, Eastern Indonesia, Borneo, and Celebes. Meanwhile, Bugis people take waterways as a part of life, Bajau people live in a more extreme principle when it comes to perspective over maritime. Bajau people consider themselves landless and base their life on the sea, living in pile boathouses, and depending on their material life. There is a Bajau old saying, "kita punya kebun di laut", means "our garden is the sea". They also believe that the sea is where the mbo madilao (ancestors of the sea) settle. This name identifies seven entities led by Mbo Janggo. Indeed, they are highly skilled at boat building, navigation, and watercraft and aware of the water environment. Within the Bajo society, both orthodox and syncretic Muslims view their cosmology upon the sea life cycle. Even the orthodox Muslims instead spend their life on the boathouse, unless it is Ramadan when they fast in the land settlements. For the syncretic Bajau people, magic rituals are involved, for instance, pangatonang bidu' (craft of boat building) and pangatonang a'nakoda/punggawa, which means the craft of fishing, sailing, and controlling the marine world $[17,18]$. 
Similar to the Bugis people, Bajau sailors depend on the east and west monsoon. They are hunting fishes in four categories, such as nubba (gleaning), pali libu (inshore coastal fishing), pongka (reef fishing), and lama (nomadic fishing for a relatively larger scale of fishing). As a community of artisanal fishing communities, the Bajau people utilize simple gears, namely trolling (tonda) hook and lines (missi), throw net (ringgi, tokong, jalla), spears (sapa), and traps. During my visit to Karimunjawa Island in 2018, I met several men of Bajau and Bugis descent. They showed me that manual spear guns (pana) are favored to catch reef fishes on a small scale, including barracuda that appears near the corals, mainly in the afternoon. In modern times, the Bajau fishing communities begin to dive with hookah, a simple breathing apparatus that allows them to dive deeper to catch reef fish, lobster, trochus, and sea cucumber (bala) by hand. Other nubba and pongka creatures that is common in Karimunjawa is popular as tetehe (sea urchin). The Bajau people go hunting in a small group, usually involved with their family members, including children and women. Nowadays, they ride motorized boats instead of the traditional perahu lambo. Besides fulfilling their domestic needs, they supply the local market with their goods, sometimes even expanding to small traders that supply external markets so that they have to hunt throughout the year. However, the Bajau people only hunt to supply themselves [18].

The Bajau people used to be known to commit illegal fishing and overfishing. Polluting the environment was committed due to unacknowledged solutions to their domestic survival problem. The mining and logging industry near their area made it challenging for them to fish, so that they blast-fished using dynamite and poison that jeopardized the coral reefs. However, it has been illegalized by the authorities; it is categorical news that the Bajau people halted using illegal gear [17]. Since 2011, explosives and poisons have been outlawed in Karimunjawa, so illegal practices are impeded significantly [12].

The variations of fishing activities, alternating between short-range fishing and nomadic fishing, and fishing for market supplies nor solely domestic supplies, contribute to balancing the dynamics of ecological biodiversity in the sea route of Bajau fishing communities. Even outside Karimunjawa Island itself, the Bajau customary contributes to the conservation of whale sharks. The custom transmitted by the elders forbids the catch of whale sharks. It also works for the other large-sized marine species in the total area, believing that spirits guard these creatures. Thus, to achieve SDG 2030 number 14, it is proven as an ideal method to engage natural and sociocultural science in the research to develop strategies of conserving threatened species. The orientation to eco-tourism relies on community monitoring involvement, including scientific research and small-scale fisheries. The supply allows stakeholders to optimize their attempt for better marine ecological management [19].

Better management of external factors affects the conformity of Bajau people towards fishing policies, helping them re-utilize the eco-artisanal fishing gears that support the ecosystem and maritime tourism. The local wisdom of Bajau people could be adopted by environment management science to achieve the expected environment. For example, in Karimunjawa Island, studies say that 1,412 units of fishing lines would be effective in practicing sustainable coral reef fishing. In comparison, the number of bubu should be reduced to 120 units. To enforce this towards the artisanal fishermen, policy should be made amongst institutions, namely BTNKJ, local Marine and Fisheries Affairs officers, local government, and environmental-oriented non-governmental organizations [20]. In Karimunjawa, those are the Karimunjawa National Park Authority (Balai Taman Nasional Karimunjawa), Taka, Yayasan 27 Pulo, HPI, Segoro, LSM Karimun, UCCU Underwater Coastal Clean-up Group, Wildlife Conservation Societies, and Diponegoro University research groups that have stood as the stakeholders that support ecological management of the national marine park through surveillance, monitoring, and conservation [12].

On the other hand, it is not only the fishing practices that can help augment sustainability that indirectly supports eco-tourism. Stakeholders such as media, NGOs, and people outside 
the fishing communities should help highlight the Bugis and Bajau traditional local wisdom as a selling point of cultural tourism. Therefore, it enables us to entice traditional culture as a brilliant solution for modern sustainability problems. It is based on the fact that traditional artisanal fishers know the ecosystem of their fishing grounds. Food web, habitat interaction, and interspecies trophic relationships are within their local wisdom that redounds to the assessment of the maritime ecosystem model [21].

\subsection{Displaying assessment of how artisanal fisheries might retain ecosystem biodiversity}

Artisanal fisheries do not necessarily always have to be subsistent. It can also be commercial purpose: however, the small-scale catches and less sophisticated technology generate it-tends to follow the natural dynamics. Despite the lower amount of catch, artisanal fisheries can also supply the market. The artisanal fisheries sector supplies human consumption more than industrial fisheries, which are also allocated to animal feeds. In Karimunjawa, the local market distributes fish supplied by artisanal fishermen. Artisanal fisheries products are also provided in the island plaza, where people local sell foods and souvenirs. As foreign tourists are abundant, we may also say that artisanal fisheries can supply the international market and tourism. One time, I noticed that many fishes had a hole on their body, which signifies that they were caught with a spear gun (pana) by hand. In Karimunjawa - according to my interview with Didik Ristanto, a law enforcement officer from the Ministry of Marine and Fisheries that has observed and operated surveillance in Karimunjawa since the end of the 1980 's - most Bugis and Bajau fishers are collaborating with small vendors that regularly distribute their catches in the kiosk at the traditional market. These vendors can also occupy their patrons due to the permanent collaboration that helps Bugis and Bajau fishers earn money. Indeed, the concept of MPA should apply here, too, in which fish stocks portion are restricted to prevent overexploitation $[21,22,23]$.

Artisanal fisheries alone cannot solve the problem of marine exploitation. Multiple approaches are required. But it is establishing a policy that allows artisanal fisheries to go along with the large-scale fisheries and offers a bright future for the artisanal fisheries culture, allowing the fisheries industry to balance the hunting practices that help retain biodiversity. To provide more well-being rights towards artisanal fishing communities, it takes socialization to attain sustainable interaction between maritime communities and the sea environment [24]. Enough data collection is also essential to determine the priority of marine law enforcement based on a specific category. That might be data about species abundance in each fishing ground, fishing gear used in the estuarine, and spatial data. This will control the activities of fisheries in general and serve reciprocity with the artisanal fishing communities. For example, an unexploited fishing ground will help artisanal fisher's economics and supply the market and tourism at the same time, while estuarine biodiversity is ensured. It is proven that priority-based enforcement in the marine protected areas based on species abundance can increase fisher revenue [25]. For maritime tourism, ecological biodiversity benefits a lot as a selling value for the attraction. From the perspective of leading tourism, the government's excellent natural conservation and management would build an image of good tourism in a country. For developing countries, it is essential to keep their positive image, especially in the media coverage, of tourism destinations, for many of them rely on natural tourism [26].

The discourse about marine protected areas enforcement might lead to a question, how does a maritime society survive if they distribute fewer commercial catches? It is a challenge to transfer a maritime society to expand their skills and transfer to another sector. Here, both livelihood of biodiversity and food availability should be ascertained through socioeconomic management that shapes human fishery behavior [27]. 
However, the policy of preserving artisanal fisheries' environmental-friendly culture does come up with a solution. As it creates a better environment for tourism, maritime society can now also rely on eco-tourism to sustain their living. Eco-tourism promotes local economics and stresses and engages tourists to contribute to conserving the marine environment. However, it is followed by a further notice that tourism should minimize threats that cause lower water quality, disease, and coral reefs decline. In many cases, they are caused by unmindful tourism. Up until 2016, coral bleaching was still an ongoing issue to tackle [12, 28]. The regulation that prohibits tourists from trampling on the coral reefs helps to avert coral reefs from bleaching. Hence, a better image of the destination attracts more tourists, nationally and internationally. According to Ristanto, the maritime society in Karimunjawa had created a harmonic structure that involves tolerance between different ethnicities in Karimunjawa. For instance, the indigenous and majority of Javanese choose to work in other sectors, such as homestay, boat renting, and snorkeling gear business, as the Madura people work in the commercial sector. The Bugis and Bajau do not have to share their fishing grounds.

Not limited to that, the Bugis and Bajau people - who reside in Kemujan, in Karimunjawa themselves have grown aware that they are responsible for the underwater life in Karimunjawa and that people depend on the ecological health of the coral reef and seagrass bed-dominated pattern, that they manage to limit their catches to prevent overexploitation. Karimunjawa is likely to be an example of a well-sustained marine environment that attracts international tourism.

\section{Conclusion}

Traditional artisanal fishers of Bugis and Bajau descent in Karimunjawa tends to catch lower amounts of fish, both for domestic and commercial purpose in a foreign tourist-crowded are. Their local wisdom of environmental awareness, fishing techniques, and gears tend to retain the biodiversity of the underwater ecosystem in Karimunjawa, Indonesia. To support the environment and economics simultaneously, these traditional fishers should be protected by the authorities and non-governmental organizations to maintain the revenue of their catch by preventing large-scale fishing overexploitation that harms artisanal fishers' economics and grounds.Itt is also crucial to ban harmful gear such as dynamite and poisons and get the Bugis and Bajau culture promoted as a tourism asset to reach the standard condition. Mirroring from the model of Karimunjawa, the economy of artisanal fishing communities is not threatened by the enforcement of fish exploitation. However, it is balanced by promoting marine eco-tourism that demands stakeholders and tourists' involvement in supporting underwater protection. Therefore, the idea of developing research, protecting traditional artisanal fisheries culture, and amassing multi-stakeholders to co-create a healthy underwater ecosystem, is an ideal solution to reach the goals of SDG no. 14, Life Below Water, which support not only environmental sustainability but also indigenous culture, tourism, and local well-being.

The authors would like to thank Department of History, Universitas Diponegoro, for funding this publication, Faculty of Humanities, Universitas Diponegoro, for facilitating the dissemination of this research through ICENIS conference, and Didik Ristanto as a respectable informant about Bugis-Bajau artisanal fisheries in Karimunjawa Island.

\section{References}


1. Y. Gao, Sustainability Assessment of Maritime Tourism Industry Based on Uncertain Evidential Reasoning Approach in the Context of Big Data and Internet, J. Coast. Res., 749-753 (2019)

2. Q. Yang, M. Su, Y. Wu, X. Wang, Economic Efficiency Evaluation of Coastal Tourism Cities Based on Fractal Theory, J. Coast. Res., 836-842 (2019)

3. W. Liu, Z. Cao, Positive Role of Marine Tourism on Economic Stimulus in Coastal Area, J. Coast. Res., 217-220 (2018)

4. L. Wang, H. Zhang, The Impact of Marine Tourism Resources Development on Sustainable Development of Marine Economy, J. Coast. Res., 589-592 (2019)

5. I. Scholz, Reflecting on the Right to Development from the Perspective of Global Environmental Change and the 2030 Agenda for Sustainable Development, in Sustainable Development Goals and Human Rights, Cham, 191-206 (2020)

6. P. Bettelli, What the World Learned Setting Development Goals, International Institute for Sustainable Development (IISD), (2021)

7. B. Clarke, R. Thurstan, K. Yates, Stakeholder Perceptions of a Coastal Marine Protected Area, J. Coast. Res., 622-626 (2016)

8. Y. Rochwulaningsih, Pattern of Center Periphery Relationship in Small Islands: A Case Study in Karimunjawa Islands, Indonesia, Int. J. Mar. Sci., 4(22), 197-209, (2014)

9. A. Begossi, Ecological, cultural, and economic approaches to managing artisanal fisheries, Environ. Dev. Sustain., 16(1), 5-34 (2014)

10. T. Suliyati, Harmoni dalam Pelestarian Budaya Etnis Bugis di Kepulauan Karimunjawa, Sabda J. Kaji. Kebud., 11, 61-71 (2016)

11. Biosafety Unit, (May, 2021), Ecosystem Approach, Retrieved from https://www.cbd.int/ecosystem/

12. E. V. Kennedy et al., Coral Reef Community Changes in Karimunjawa National Park, Indonesia: Assessing the Efficacy of Management in the Face of Local and Global Stressors, J. Mar. Sci. Eng., 8(10), (2020)

13. L. Y. Andaya, The Bugis-Makassar Diasporas, J. Malays. Branch R. Asiat. Soc., 68(1), 119-138 (1995)

14. C. Pelras, The Bugis, Oxford, OX, UK; Cambridge, Mass., (Blackwell Publishers USA, 1996)

15. G. Ammarell, Bugis Migration and Modes of Adaptation to Local Situstions, Ethnology, 41(1), 51-67 (2002)

16. G. Ammarell, Knowing When to Set Sail: Practical Knowledge and Simple Heuristics in Bugis Navigational Strategies, Bijdr. Tot Taal- Land- En Volkenkd., 158(2), 191-223 (2002)

17. T. G. Hoogervorst, Ethnicity and aquatic lifestyles: exploring Southeast Asia's past and present seascapes, Water Hist., 4(3), 245-265, (2012)

18. N. Stacey, The Maritime World of the Bajo, in Boats to Burn, ANU Press, 2, 31-56 (2007)

19. N. E. Stacey, J. Karam, M. G. Meekan, S. Pickering, J. Ninef, Prospects for Whale Shark Conservation in Eastern Indonesia Through Bajo Traditional Ecological Knowledge and Community-based Monitoring, Conserv. Soc., 10(1), 63-75 (2012)

20. R. Irnawati, D. Simbolon, B. Wiryawan, B. Murdiyanto, Model pengelolaan perikanan karang di Taman Nasional Karimunjawa, 35(1), 12

21. A. M. Cisneros-Montemayor, M. J. Zetina-Rejón, M. J. Espinosa-Romero, M. A. Cisneros-Mata, G. G. Singh, aF. J. Fernández-Rivera Melo, Evaluating ecosystem 
impacts of data-limited artisanal fisheries through ecosystem modelling and traditional fisher knowledge, Ocean Coast. Manag., 195, 105291 (2020)

22. A. Halim et al., Developing a functional definition of small-scale fisheries in support of marine capture fisheries management in Indonesia, Mar. Policy, 100, 238-248 (2019)

23. M. Andrellom F. Guilhaumon, C. Albouy, V. Parravicini, J. Scholtens, P. Verley, M. Barange, U. R. Sumaila, S. Manel, D. Mouillot, Global mismatch between fishing dependency and larval supply from marine reserves, Nature Communications, 8, 16039 (2017)

24. T. H. Frawley, E. M. Finkbeiner, L. B. Crowder, Environmental and institutional degradation in the globalized economy: lessons from small-scale fisheries in the Gulf of California, Ecol. Soc., 24(1), (2019)

25. M. D. de Paula Costa, M. Mills, A. J. Richardson, R. A. Fuller, J. H. Muelbert, H. P. Possingham, Efficiently enforcing artisanal fisheries to protect estuarine biodiversity, Ecol. Appl., 28(6), 1450-1458 (2018)

26. E. Avraham, Changing the Conversation: How Developing Countries Handle the International Media during Disasters, Conflicts, and Tourism Crises, J. Inf. Policy, 7, 275-296 (2017)

27. C. Bieg et al., Linking humans to food webs: a framework for the classification of global fisheries, Front. Ecol. Environ., 16(7), 412-420 (2018)

28. M. Syam, T. Aprillia, I. Maulana, Ecotourism: An alternative of socio-ecological crisis?, IOP Conf. Ser; Earth Environ, 241, 012017 (2019) 